\title{
A model study of the pollution effects of the first 3 months of the Holuhraun volcanic fissure: comparison with observations and air pollution effects
}

\author{
Birthe Marie Steensen $^{1}$, Michael Schulz ${ }^{1}$, Nicolas Theys ${ }^{2}$, and Hilde Fagerli ${ }^{1}$ \\ ${ }^{1}$ Division for climate modelling and air pollution, Norwegian Meteorological Institute, Postbox 43 Blindern, 0313 Oslo, \\ Norway \\ ${ }^{2}$ Atmospheric composition, Belgian Institute for Space Aeronomy, Ringlaan-3-Avenue Circulaire, 1180 Brussels, Belgium \\ Correspondence to: Birthe Marie Steensen (birthems@met.no)
}

Received: 9 November 2015 - Published in Atmos. Chem. Phys. Discuss.: 25 January 2016

Revised: 13 June 2016 - Accepted: 9 July 2016 - Published: 3 August 2016

\begin{abstract}
The volcanic fissure at Holuhraun, Iceland started at the end of August 2014 and continued for 6 months to the end of February 2015, with an extensive lava flow onto the Holuhraun plain. This event was associated with large $\mathrm{SO}_{2}$ emissions, amounting up to approximately 4.5 times the daily anthropogenic $\mathrm{SO}_{2}$ emitted from the 28 European Union countries, Norway, Switzerland and Iceland. In this paper we present results from EMEP/MSC-W model simulations to which we added $750 \mathrm{~kg} \mathrm{~s}^{-1} \mathrm{SO}_{2}$ emissions at the Holuhraun plain from September to November (SON), testing three different emission heights. The three simulated $\mathrm{SO}_{2}$ concentrations, weighted with the OMI (Ozone Monitoring Instrument) satellite averaging kernel, are found to be within $30 \%$ of the satellite-observed $\mathrm{SO}_{2}$ column burden. Constraining the $\mathrm{SO}_{2}$ column burden with the satellite data while using the kernel along with the three simulated height distributions of $\mathrm{SO}_{2}$, we estimate that the median of the daily burdens may have been between 13 and $40 \mathrm{kt}$ in the North Atlantic area under investigation. We suggest this to be the uncertainty in the satellite-derived burdens of $\mathrm{SO}_{2}$, mainly due to the unknown vertical distribution of $\mathrm{SO}_{2}$. Surface observations in Europe outside Iceland showed concentration increases up to $>500 \mu \mathrm{g} \mathrm{m}^{-3} \mathrm{SO}_{2}$ from volcanic plumes passing. Three well identified episodes, where the plume crossed several countries, are compared in detail to surface measurements. For all events, the general timing of the observed concentration peaks compared quite well to the model results. The overall changes to the European $\mathrm{SO}_{2}$ budget due to the volcanic fissure are estimated. Three-monthly wet deposition
\end{abstract}

(SON) of $\mathrm{SO}_{x}$ in the 28 European Union countries, Norway and Switzerland is found to be more than $30 \%$ higher in the model simulation with Holuhraun emissions compared to a model simulation with no Holuhraun emissions. The largest increases, apart from extreme values on Iceland, are found on the coast of northern Norway, a region with frequent precipitation during westerly winds. Over a 3-month average (during SON 2014) over Europe, $\mathrm{SO}_{2}$ and $\mathrm{PM}_{2.5}$ surface concentrations, due to the volcanic emissions, increased by only ten and $6 \%$ respectively. Although the percent increase of $\mathrm{PM}_{2.5}$ concentration is highest over Scandinavia and Scotland, an increase in PM exceedance days is found over Ireland and the already polluted Benelux region (up to 3 additional days), where any small increase in particulate matter concentration leads to an increase in exceedance days.

\section{Introduction}

Increased seismic activity in the Bárðarbunga volcano was recorded by the Icelandic Met Office from the middle of August 2014 (http://en.vedur.is/earthquakes-and-volcanism/ volcanic-eruptions/holuhraun/). The activity continued in the volcano but some tremors also appeared towards the Holuhraun plain, a large lava field north of the Vatnajökull ice cap, the latter covering the Bárðarbunga and Grimsvötn volcano. On 31 August a continuous eruption started at Holuhraun with large amounts of lava pouring onto the plain and large amounts of sulfur dioxide $\left(\mathrm{SO}_{2}\right)$ emitted into the at- 
mosphere (Sigmundsson et al., 2015). Thordarson and Hartley (2015) estimated $\mathrm{SO}_{2}$ emissions from the magma at Holuhraun to range between 30 and $120 \mathrm{kt} \mathrm{d}^{-1}$ over the first 3 months of the eruption, with a maximum during the first 2 weeks of September. Schmidt et al. (2015) also found that among several model simulations with different emission fluxes, the model simulations with the largest emission $\left(120 \mathrm{ktd}^{-1}\right)$ compared best with satellite observations at the beginning of September. In comparison, Kuenen et al. (2014) estimated the daily anthropogenic emission from the $28 \mathrm{Eu}-$ ropean Union countries for 2009 to be $13.9 \mathrm{ktd}^{-1}$, while the 2013 estimate is $9.8 \mathrm{ktd}^{-1}$ (EMEP, 2015). The eruption ended in February 2015 and during the 6 months of eruption a total of approximately $11( \pm 5) \mathrm{Tg} \mathrm{SO}_{2}$ may have been released (Gíslason et al., 2015), and the total lava field from the fissure measured $85 \mathrm{~km}^{2}$ in area with a lava volume estimated to amount to $1.4 \mathrm{~km}^{3}$ (vedur.is). It is of interest to investigate the impact of these volcanic emissions on $\mathrm{SO}_{2}$ levels in $\mathrm{Eu}-$ rope in 2014. In the last decades, measures have been taken to reduce $\mathrm{SO}_{2}$ emissions, triggered by the Convention on Longrange Transboundary Air Pollution (LRTAP), in Europe. Significant reductions of $75 \%$ in emission between 1980 and 2010 are confirmed by observations (Tørseth et al., 2012). The impact of volcanic eruptions with $\mathrm{SO}_{2}$ emissions can thus perturb the European atmospheric sulfur budget to a larger extent than before and potentially lead to new acidification of lakes and soils if the eruption lasts over a long time period.

For comparison, the big 1783 Icelandic Laki eruption lasted 8 months and released a total amount of estimated $120 \mathrm{Tg}$ of $\mathrm{SO}_{2}$. The resulting sulfuric acid caused a haze observed in many countries in the Northern Hemisphere and increased mortality in northern Europe (Grattan et al., 2003; Thordarson and Self, 2003; Schmidt et al., 2011). The fissure at Holuhraun was much weaker than the Laki fissure, both in terms of amount of $\mathrm{SO}_{2}$ released and probably also the height of the eruptive column. Thordarson and Self (1993) estimated that the Laki erupted at emission heights up to $15 \mathrm{~km}$, while the observations of the Holuhraun eruptive cloud saw the plume rising up to $5 \mathrm{~km}$ (vedur.is). Ground-level concentrations exceeded the Icelandic hourly average health limit of $350 \mathrm{\mu gm}^{-3}$ over large parts of Iceland (Gíslason et al., 2015). The World Health Organization (WHO) has a $10 \mathrm{~min}$ limit

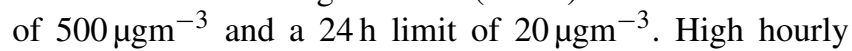
mean surface concentrations of $\mathrm{SO}_{2}$ were measured in Ireland $\left(524.2 \mu \mathrm{gm}^{-3}\right)$, then also in Austria $\left(247.0 \mu \mathrm{gm}^{-3}\right)$ and Finland $\left(180 \mu \mathrm{gm}^{-3}\right)$ (Schmidt et al., 2015; Ialongo et al., 2015).

A climate impact of high $\mathrm{SO}_{2}$ emissions may be suspected, such as a cooling of climate due to an increase in aerosol burdens. Gettelman et al. (2015), using a global climate model, found a small increase in cloud albedo due to the Holuhraun emissions resulting in a $-0.21 \mathrm{Wm}^{-2}$ difference in radiative flux at the top of the atmosphere. If the event had happened earlier in the summer, a larger radiative effect could be expected $\left(-7.4 \mathrm{Wm}^{-2}\right)$. Understanding the atmospheric sulfur budget associated to such events is thus of great interest also for climate science. Unlike the two previous big eruptions in Iceland, Eyjafjallajökull in 2010 and Grímsvötn in 2011, this eruption did not emit significant amounts of ash. However, uncertainties in volcanic source estimates, timevarying emissions from a volcano type of point source and dependence of transport on initial injection height are similar problems for $\mathrm{SO}_{2}$ and ash plumes. For eruptions in which both ash and $\mathrm{SO}_{2}$ are emitted, $\mathrm{SO}_{2}$ can act as a proxy for ash (Thomas and Prata et al., 2011; Sears et al., 2013), however separation will occur because of density differences and different eruption heights (Moxnes et al., 2014). Proven capability of modelling the transport of a volcanic plume can be useful for judging future eruption scenarios where $\mathrm{SO}_{2}$ or ash can cause a problem.

The Holuhraun eruption is worth being analysed for several gas and aerosol transport and transformation processes, this study will mainly focus on simulated air quality effects and the perturbed sulfur budget due to the volcanic $\mathrm{SO}_{2}$ emissions during the first 3 months of the eruption. Several stations in Europe reported high concentrations of $\mathrm{SO}_{2}$ during this time and case studies are chosen to evaluate simulated plume development over Europe. The transport is modelled with the EMEP MSC-W chemical transport model, one of the important models used for air quality policy support in Europe over the last 30 years (Simpson et al., 2012). The first 2 months of the eruption are well covered by satellite observations. Both station and satellite data are compared to model results to understand the amplitude and magnitude of the sulfur budget perturbation. The effect of the injection height on the model results is studied by sensitivity simulations. Finally the perturbed European sulfur budget is documented and discussed to investigate the impact of increased $\mathrm{SO}_{2}$ emission from a Icelandic volcano on European pollution levels.

\section{Methods}

\subsection{Model description}

The model simulations of the transport of the $\mathrm{SO}_{2}$ Holuhraun emissions are created with the 3-D Eulerian chemical transport model developed at the Meteorological Synthesizing Centre - West (MSC-W) for the European Monitoring and Evaluation Programme (EMEP). The EMEP MSC-W model is described in Simpson et al. (2012). $\mathrm{SO}_{2}$ is oxidized to sulfate in both gas and aqueous phase. In gas phase the oxidation is initiated by $\mathrm{OH}$ and is controlled by local chemistry. In aqueous phase the oxidants ozone, hydrogen peroxide and oxygen catalysed eventually by metal ions contribute to the oxidation. The dry deposition in the model is parameterized for different land types. Both in-cloud and subcloud scavenging are considered for wet deposition. 
The simulations use the EMEP-MACC (Monitoring Atmospheric Composition and Climate) model configuration. The horizontal resolution of the model simulations is $0.25^{\circ}$ (longitude) $\times 0.125^{\circ}$ (latitude). There are 20 vertical layers up to about $100 \mathrm{hPa}$, with the lowest layer around $90 \mathrm{~m}$ thick. The model is driven by meteorology from the European Centre of Medium-Range Weather Forecasts (ECMWF) in the MACC model domain $\left(30^{\circ} \mathrm{W}\right.$ to $45^{\circ} \mathrm{E}$ and 30 to $\left.76^{\circ} \mathrm{N}\right)$. Iceland is in the upper north-western corner of the domain, which implies losses of sulfur from the regional budget terms in sustained southerly and easterly flow regimes. The meteorology fields used have been accumulated in the course of running the MACC regional model ensemble forecast of chemical weather over Europe (http://macc-raq-op.meteo. fr), of which the EMEP MSC-W model is a part. For our hindcast-type simulations here, only the fields from the first day of each forecast are used. The meteorology is available with a $3 \mathrm{~h}$ interval. All model simulations are run from September through to November 2014.

Emission from the Holuhraun fissure is set to a constant $750 \mathrm{kgs}^{-1} \mathrm{SO}_{2}\left(65 \mathrm{ktd}^{-1}\right)$ for the entire simulation from the total $2.0 \pm 0.6 \mathrm{Tg} \mathrm{\textrm {SO } _ { 2 }}$ emitted in September estimated in Schmidt et al. (2015). For all model runs the anthropogenic emissions are standard for our EMEP MACC model configuration. Table 1 shows an overview of the four different model runs that are used in this study. The column height observed both at ground and airborne instruments, varied during the eruption (Schmidt et al., 2015), the mean height was however around $3 \mathrm{~km}$ over the period. For the best guess, base case simulation, called bas_hol, volcanic emissions at Holuhraun are distributed equally from the ground up to a $3 \mathrm{~km}$ emission column height. To test the sensitivity towards emission height, two additional model simulations are carried out. One simulation in which the volcanic emission is distributed from the ground up to $1 \mathrm{~km}$ called low_hol, and a simulation in which the volcanic emission is distributed between $3 \mathrm{~km}$ and $5 \mathrm{~km}$ called high_hol. To derive the impact purely due to the emissions from Holuhraun, a simulation with no Holuhraun emissions is performed, called no_hol. Sensitivity runs with an almost doubled constant emission rate of $1400 \mathrm{kgs}^{-1}$, and a time-varying emission term given in Thordarson and Hartley (2015) were also studied. These resulted in an almost linear increase in concentrations and deposition and did not compare better to observations and will therefore not be presented here. The sensitivity to height of the emission appeared to be more important and is shown here in more detail.

Anthropogenic $\mathrm{SO}_{2}$ emissions in the model are described in Kuenen et al. (2014). There is a yearly total $\mathrm{SO}_{2}$ emission of $13.2 \mathrm{Tg} \mathrm{a}^{-1}$ corresponding to 2009 conditions, the same year that is used in the reference MACC model configuration. The difference to actual 2014 conditions is assumed to be unimportant here. The inventory includes $2.34 \mathrm{Tga}^{-1} \mathrm{SO}_{2}$ in yearly ship emissions over the oceans. Over the continents the yearly emissions are $5.08 \mathrm{Tga}^{-1} \mathrm{SO}_{2}$ for the $28 \mathrm{EU}$ coun- tries and $5.53 \mathrm{Tga}^{-1} \mathrm{SO}_{2}$ for the non-EU countries in the MACC domain (including Iceland) covered by the MACC domain.

\subsection{Observations}

The satellite data used in this study stem from the Ozone Monitoring Instrument (OMI) aboard NASA AURA (Levelt et al., 2006). The satellite was launched in July 2004 as part of the A-train earth-observing satellite configuration and follows a sun-synchronous polar orbit. The OMI measures backscattered sunlight from the Earth's atmosphere with a spectrometer covering UV and visible wavelength ranges. Measurements are therefore only available during the daytime. The background $\mathrm{SO}_{2}$ concentrations are often too low to be observable, but increases in $\mathrm{SO}_{2}$ from volcanic eruptions can produce easily distinguishable absorption effects (Brenot et al., 2014). Pixel size varies between $13 \mathrm{~km} \times 24 \mathrm{~km}$ at nadir and $13 \mathrm{~km} \times 128 \mathrm{~km}$ at the edge of the swath. OMI satellite data are affected by "row anomalies" due to a blockage affecting the nadir viewing part of the sensor, which affects particular viewing angles and reduces the data coverage. The zoom-mode of OMI reduces the coverage on some days. The coverage is also reduced by missing daylight, e.g. winter observations from high latitudes are absent. Therefore data from only the first 2 months from September until the end of October are used in this study.

The retrievals are described in Theys et al. (2015). The sensitivity of backscatter radiation to $\mathrm{SO}_{2}$ molecules varies with altitude (generally decreasing towards the ground level), therefore the algorithms use an assumed height distribution for estimating the integrated $\mathrm{SO}_{2}$ column density. Since often little information is available at the time of eruption and the retrievals produce results daily (even for days with no eruption), an assumed a priori profile is used for the vertical $\mathrm{SO}_{2}$ distribution. The satellite retrievals used here assume an a priori profile with a plume thickness of $1 \mathrm{~km}$ that is centred at $7 \mathrm{~km}$, similar to the method described in Yang et al. (2007). As found in Schmidt et al. (2015), this is too high for the Bárðarbunga eruption. Therefore, the retrieved $\mathrm{SO}_{2}$ column densities may be too low. To compare the vertical column density (VCD) from the model to the one from satellite retrievals, the averaging kernel from the satellite has to be used. Each element of an averaging kernel vector defines the relative weight of the true partial column value in a given layer to the retrieved vertical column (Rodgers, 2000). Cloud cover also changes the averaging kernel and a spatio-temporally changing kernel is part of the satellite data product (an averaging kernel is provided for each satellite pixel).

To apply the averaging kernel on model data, the satellite data are regridded to the model grid so that those data from satellite pixels nearest to any given model grid point are used for that grid point. A smaller area than the whole model domain was chosen to study and be compared to the satellite data, $30^{\circ} \mathrm{W}$ to $15^{\circ} \mathrm{E}$ and 45 to $70^{\circ} \mathrm{N}$ (red boxes in 
Table 1. Overview of model runs and the Holuhraun $\mathrm{SO}_{2}$ emission height assumptions and flux; given are also medians of daily mass burdens of $\mathrm{SO}_{2}$ for September to October 2014 in the North Atlantic as described along with Figs. 2 and 3.; last column contains scaled mass burdens, assuming $7.0 \mathrm{kt}$ of $\mathrm{SO}_{2}$ burden derived from satellite data (see text in discussion).

\begin{tabular}{lcrccc}
\hline $\begin{array}{l}\text { Model } \\
\text { simulation } \\
\text { name }\end{array}$ & $\begin{array}{c}\text { Emission } \\
\text { injection } \\
\text { layer [km] }\end{array}$ & $\begin{array}{r}\text { Emission } \\
\text { flux } \\
\left(\mathrm{kg} \mathrm{s}^{-1}\right)\end{array}$ & $\begin{array}{c}\text { Burden } \\
\text { original } \\
(\mathrm{kt})\end{array}$ & $\begin{array}{c}\text { Burden } \\
\text { kernel } \\
\text { weighted (kt) }\end{array}$ & $\begin{array}{c}\text { Mass } \\
\text { burden } \\
\text { scaled (kt) }\end{array}$ \\
\hline bas_hol & $0-3$ & 750 & 22.5 & 7.4 & 21.4 \\
low_hol & $0-1$ & 750 & 25.4 & 4.4 & 40.3 \\
high_hol & $3-5$ & 750 & 15.9 & 8.3 & 13.4 \\
no_hol & & 0 & & & \\
\hline
\end{tabular}

Fig. 1). The Aura satellite makes five overpasses over the domain during the daytime and swaths are partly overlapping in the northern regions. For the grid cells where the swaths overlap, the satellite observations are averaged to produce daily average fields. There are also regions that are not covered by satellite observation that will not be taken into account in the model data post processing. To make comparable daily averages of the model data, the closest hour in the hourly model output are matched to the satellite swath time and only grid points that are covered by satellite are used. The profiles for the averaging kernel in the satellite product are given on 60 levels and the values from these levels are interpolated to model vertical levels. The newly adjusted model VCD is then calculated by multiplying the interpolated averaging kernel weights to the $\mathrm{SO}_{2}$ concentration in each model layer, integrating all layers with the height of each model layer.

Because of noise in the satellite data small retrieved VCD values are highly uncertain. A threshold limit is sought to identify those regions that have a significant amount of $\mathrm{SO}_{2}$. Standard deviation for the satellite data is calculated over an apparently $\mathrm{SO}_{2}$ free North Atlantic region (size $10 \times 15^{\circ}$ lat lon respectively) and is found to be around 0.13 DU. Effects of varying cloud cover are ignored. An instrument detection limit is 3 times the standard deviation of a blank, so we assume that with a threshold value set to $0.4 \mathrm{DU}$ we exclude satellite data below the detection limit. Any grid point with a value above this threshold in the satellite data is used along with the corresponding model data. Daily mass burdens for the North Atlantic region are calculated by summing up all $\mathrm{SO}_{2} \mathrm{VCD}$ in the grid cells above the threshold. Finally we convert Dobson units to mass burdens here and there in the paper to facilitate comparison to models and mass budgets. One Dobson unit is $2.69 \times 10^{20}$ molecules per square metre, which corresponds to a column burden of 28.62 milligrams $\mathrm{SO}_{2}$ per square metre $\left(\mathrm{mgm}^{-2}\right)$.

Data of $\mathrm{SO}_{2}$ and $\mathrm{PM}_{2.5}$ surface concentrations are collected by the European Environment Agency (EEA) through the European Environment Information and Observation Network (EIONET). We make use of two preliminary subsets of this data, one obtained from work within the MACC project to produce regular air quality forecasts and reanalysis (only $\mathrm{SO}_{2}$ ) and a second one obtained from EEA, a so called up-to-date (UTD) air quality database, state spring 2016 . The two different subsets cover observation data from different countries, and have not been finally quality assured at the time of writing this paper. We use only station data, which contain hourly data. However, there are missing data and some stations have instruments with high detection limits, making it difficult to create a continuous measurement series with good statistics. Therefore, in this study only some outstanding episodes with high concentrations of $\mathrm{SO}_{2}$ and documented transnational transport of a volcanic plume are analysed. For the first 6-day period between 20 and 26 September 2014, high concentrations of $\mathrm{SO}_{2}$ were measured over Great Britain and countries further to the south. For the second 6-day period, a month later (20 to 26 October), the plume was also detected over Great Britain, but was transported further east towards Germany. For the last plume studied, lasting from 29 October to 4 November, the volcanic emission was transported eastward to the coast of Norway and countries to the south. Recent daily deposition data are taken from the EBAS database (ebas.nilu.no) for those stations for which the data are already available. Model data to represent the station values are picked from hourly data at model surface level in the grid cell where the station is located.

\section{Results}

\subsection{Comparison to satellite data}

Observations by satellite provide information about $\mathrm{SO}_{2}$ location and column density. Figure 1a shows as an example the VCD from the OMI satellite overpasses on 24 September 2014. Figure $1 \mathrm{~b}$ and $\mathrm{c}$ show the modelled and the kernelweighted VCD from the base simulation (bas_hol). The observed satellite $\mathrm{SO}_{2}$ cloud and the model-simulated $\mathrm{SO}_{2}$ cloud show similar shape and location. The kernel-weighted model column densities are smaller than the original model VCDs. More weight is given by the averaging kernel to model layers higher up, close to the reference height of $7 \mathrm{~km}$, where there is less $\mathrm{SO}_{2}$ in our case, with emissions and transport happening in the lower part of the troposphere. The re- 
(a)

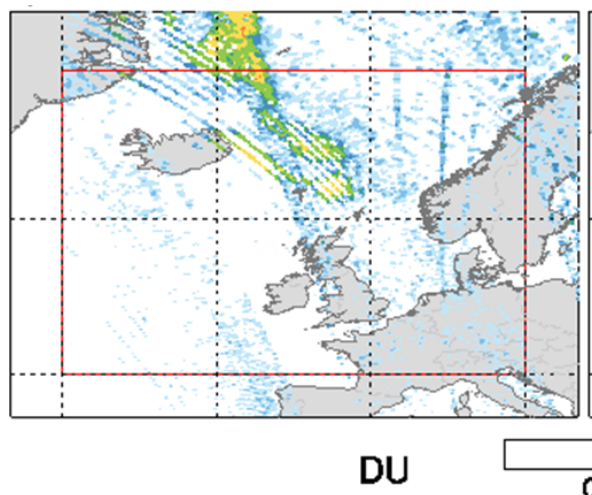

(b)

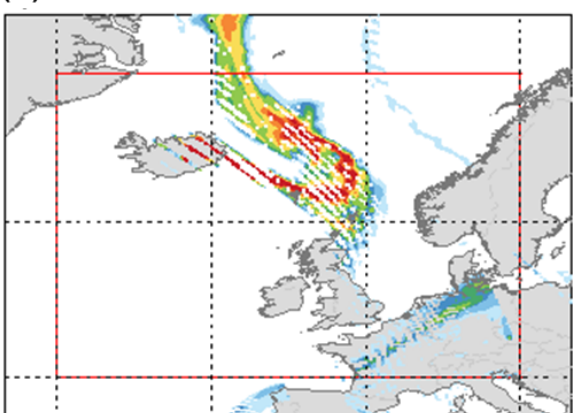

(c)

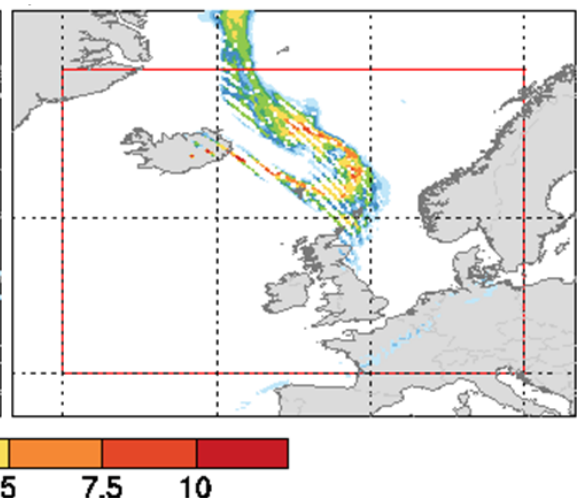

Figure 1. $\mathrm{SO}_{2}$ column density: (a) for the satellite swaths on 24 September 2014; (b) for corresponding, consistently colocated original model data in the base simulation bas_hol; (c) for these model data with the satellite averaging kernel applied. The red box indicates the area where the statistics of satellite and model data in Figs. 2 and 3 are acquired.

duced kernel-weighted column densities are closer to the column densities observed by the satellite. There are, however, some spatial differences regarding where the maximum column densities are located.

A quantitative comparison is attempted here by integrating all satellite - and corresponding model data - above the North Atlantic, between Iceland and Europe, into daily mean column burdens. Figure 2 shows the time series from September to October of daily satellite coverage and daily mass burdens considered over the area where satellite VCD values exceed the $0.4 \mathrm{DU}$ detection limit as explained above. The area covered by valid satellite observations at the beginning of the period is around $70 \%$ of the domain used here (red boxes in Fig. 1). Towards the end of the period, the satellite coverage is only around $40 \%$ because of the increasing solar zenith angle (a satellite zenith angle cut-off of $75^{\circ}$ is used for the satellite data). On some days, the satellite cover is even lower because of the OMI zoom mode. The percentage of the satellite data that is above the detection limit is low over the entire 2-month period, only reaching around $10 \%$ at the end of September and beginning of October.

On most days, the satellite daily mass burden is above the model value, ignoring the days when the OMI zoom mode is responsible for a small coverage. The average satellite-derived $\mathrm{SO}_{2}$ mass burden assuming a $7 \mathrm{~km}$ reference height is $11.2 \mathrm{kt}$, while the kernel-weighted model burden in bas_hol is $8.7 \mathrm{kt} \mathrm{SO}_{2}$. The highest values are found at the beginning of the period, $42.1 \mathrm{kt} \mathrm{SO} \mathrm{S}_{2}$ on 7 September, for the model, and $37.4 \mathrm{kt} \mathrm{SO}$, on 20 September for the satellite. Taking into account the area in which the satellite-observed $\mathrm{SO}_{2}$ is found above detection limit, the satellite average column loadings are calculated to reach $70 \mathrm{mgm}^{-2}$ for September. Furthermore, the peaks in the middle of October, visible in Fig 2b, exhibit a satellite average column loading of $62 \mathrm{mgm}^{-2}$.
The daily values of $\mathrm{SO}_{2}$ mass burden are decreasing over time, especially during October. There is also a positive bias of the model against the satellite at the end of October. At the same time the satellite coverage is decreasing along with an increasing solar zenith angle. To further investigate whether this is responsible for the general decrease in mass burdens and the increasing bias of the simulated vs. observed VCDs, a new aggregation domain further south is used. All the areas where satellite observations may be possible up to the end of October $\left(61.25^{\circ} \mathrm{N}\right)$ are used to calculate another set of daily column burdens for satellite and model data (see Fig. 2c). Satellite coverage in this southerly domain is not decreasing over time, but it is also not covering Iceland, so the $\mathrm{SO}_{2}$ from Holuhraun first needs to be transported south before it can be detected. The plume is transported that far south 4 times over the 2-month period as the peaks in column burden values in Fig. 2c show. In this southerly area the daily accumulated mass burdens are similar in September and in October, supporting the hypothesis that the apparent decrease in mass burden in Fig. $2 b$ is due to reduced satellite coverage.

Percentile values from the distribution of the daily mass burden in September and October 2014 from all three model simulations, original and kernel weighted, are shown in Fig. 3. Note that the mass burdens are accumulated in the same area in the North Atlantic, where at least 0.4 DU SO was observed by OMI. Looking at the original model data, the model simulation with emissions in the lowest kilometre (low_hol) has the highest daily mass burden values (median: $25.4 \mathrm{kt}$ ), followed by the best-guess simulation, bas_hol (median: $22.5 \mathrm{kt}$ ), while the run with the emission highest in the atmosphere (high_hol) exhibits the smallest mass burden (median: $15.9 \mathrm{kt}$ ). The higher values in the low_hol simulation can be explained by less wind and dispersion at low altitudes and thus a more concentrated $\mathrm{SO}_{2}$ cloud than in the two other model simulations. 

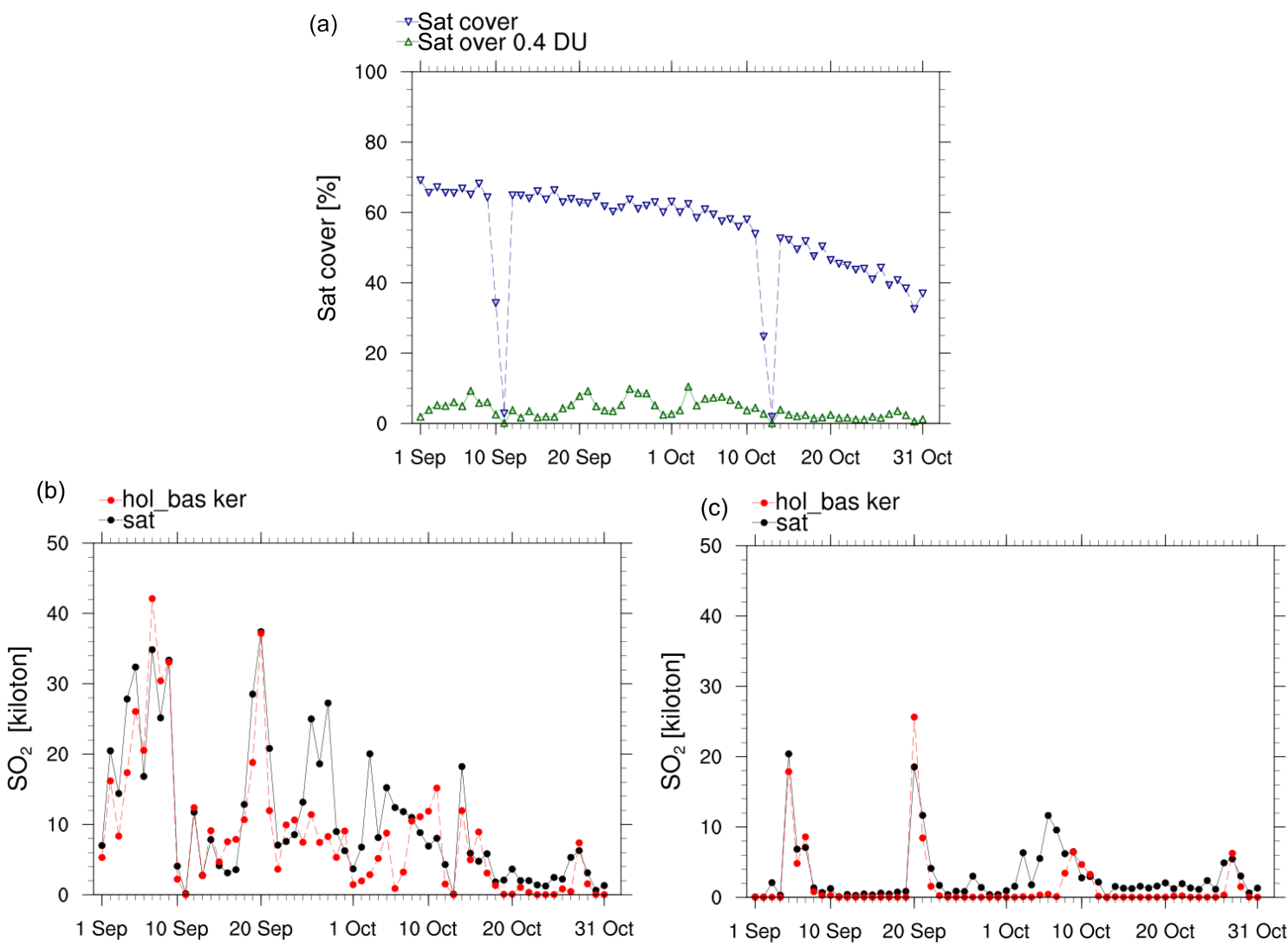

Figure 2. (a) Time series of the daily reference area covered by valid satellite observations (blue triangles) in percent of the total area of the domain used for the statistics $\left(30^{\circ} \mathrm{W}\right.$ to $15^{\circ} \mathrm{E}$ and $45-70^{\circ} \mathrm{N}$, see Fig. 1). Green triangles show the reference area in percent where satellitederived $\mathrm{SO}_{2}$ VCD is above $0.4 \mathrm{DU}$; (b) Time series of accumulated daily $\mathrm{SO}_{2}$ mass burdens in reference area from satellite data ("sat", black dots) and from model base run with averaging kernel applied ("hol_bas ker", red dots; (c) Shows the same as (b) but over a smaller area just south of $61.15^{\circ} \mathrm{N}$.

The kernel-weighted model data represent what can be directly compared to the satellite data. As shown in Fig. 3, and illustrated already in Fig. 1, the kernel-weighted model column burden values are much smaller than the original ones, because the $\mathrm{SO}_{2}$ plume was simulated to be far below $7 \mathrm{~km}$ altitude. The impact of the kernel weighting is quite different for the three model simulations. After the averaging kernel has been applied to the model data, the high_hol model simulation exhibits the highest daily burdens compared to the other two model simulations. The median for the bas_hol, low_hol and high_hol daily mass burden are 7.4, 4.4 and $8.4 \mathrm{kt}$ respectively, while the satellite mass burden median value is $7.0 \mathrm{kt}$. High burdens retrieved from satellite data, and high kernel-weighted model burdens reflect that volcanic $\mathrm{SO}_{2}$ is present at high concentrations and/or at high altitudes.

Analysis of the distribution of daily mass burdens allows for investigating how many days with very high burdens were present. Comparing the satellite data to the kernel-weighted model data, we find that the satellite's 75th percentile is larger than any of the model simulation's 75th percentiles. The satellite data contain some high daily burden values that result in a higher average burden and a higher 75 th percentile. From testing different emission heights in our three-model simulations, the best-guess bas_run has the most similar distribution of daily burdens compared to the satellite data over the first 2 months.

\subsection{Surface concentrations}

$\mathrm{SO}_{2}$ from the volcanic eruption on Holuhraun was measured at several surface stations during the period. Three different episodes with clear peaks in observed concentrations at stations around Europe are described in the following paragraphs. Exemplary comparisons are shown and additional comparisons at other stations are available in the Supplement.

A particular episode with very high surface concentrations of up to $500 \mathrm{\mu gm}^{-3} \mathrm{SO}_{2}$ in Ireland at the beginning of September was studied by Schmidt et al. (2015). However, just very few Irish station data were in the data extract we obtained from the EEA for this episode, and we decided to document the comparison for this episode in the Supplement. The comparison supports, however, that our emission flux in- 


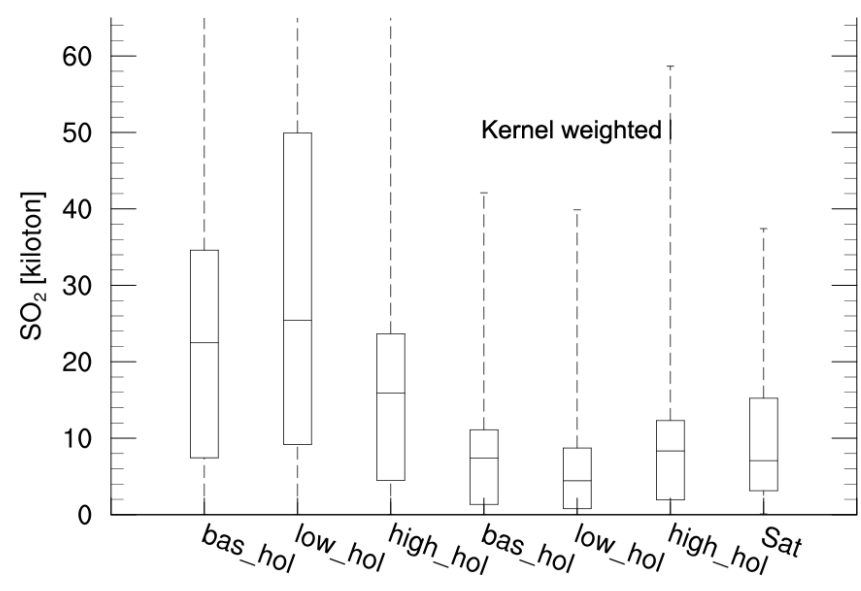

Figure 3. Distribution of daily $\mathrm{SO}_{2}$ mass burden values in the area where satellite-derived $\mathrm{SO}_{2}$ exceeds $0.4 \mathrm{DU}$ (\# 61; values from Fig. 2) as box-and-whisker plots; shown for the model simulations are original data ( 3 left boxes) and kernel-weighted data (3 following boxes) and the satellite data. The boxes shown represent the 25th percentile, the median, and the 75th percentile values, lower whiskers the minimum value and upper whiskers the maximum value.

deed might have been too small in the first days of September 2014.

Figure 4 shows the hourly time series for two stations over Great Britain and France from 20 September to 26 September. A maximum concentration of $44.3 \mu \mathrm{gm}^{-3} \mathrm{SO}_{2}$ was measured on 21 September 16 UTC at a station situated in Manchester $\left(53.48^{\circ} \mathrm{N}\right.$ and $\left.2.24^{\circ} \mathrm{W}\right)$ near the west coast of Britain. None of the three model simulations reach the observed maximum values. However, the simulated concentration field shows areas south of the station near Manchester, where the volcanic $\mathrm{SO}_{2}$ concentrations are around $50 \mu \mathrm{gm}^{-3}$. Interestingly, the agreement of the model-derived volcanic $\mathrm{SO}_{2}$ time series is better in agreement with measurements than the total simulated $\mathrm{SO}_{2}$ concentration (grey curve), indicating that the model may not resolve $\mathrm{SO}_{2}$ transport from nearby pollution sources and that the station for these days is rather representative of long-range transported volcanic $\mathrm{SO}_{2}$. Observed $\mathrm{PM}_{2.5}$ concentrations at the station show that, over the period, the highest concentration $\left(52.1{\mu \mathrm{gm}^{-3}}^{-3}-\right.$ probably anthropogenic - is measured at the start of the period, when the model did not simulate any volcanic sulfur contribution. The next day, the plume moved further south over France. The station is situated on the west coast of France in Saint-Nazaire $\left(47.25^{\circ} \mathrm{N}\right.$ and $\left.2.22^{\circ} \mathrm{W}\right)$. The measurements show three peaks over 3 days, with the highest one $\left(38 \mathrm{\mu gm}^{-3}\right)$ measured on the 23 September at 12:00 UTC. All three model simulations have peak concentrations which are earlier than the observed ones, and the concentrations from the model are lower than observed. The three simulations do, however, show increased concentrations at the site due to the volcanic eruption over the 3 days. The map shows that large parts of France had an increase in $\mathrm{SO}_{2}$ surface concentrations during this time.

Figure 5 shows the time series for three stations over Scotland and Germany a month later, from 20 to 26 October. The high_hol simulation shows low concentrations over the Scottish Grangemouth station $\left(56.01^{\circ} \mathrm{N}\right.$ and $\left.3.70^{\circ} \mathrm{W}\right)$, but the bas_hol and low_hol have a plume with high concentrations over the station on 20 October. There are no measurements at this time with which to compare the model values. The timing of the second plume on 21 October for the two models is a few hours early and the modelled concentrations higher than

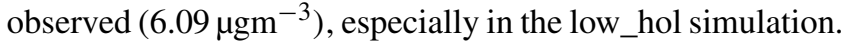
The map shows a narrow plume from Iceland southwards to Scotland and the station lies on the edge of this plume. On 22 October, the volcanic $\mathrm{SO}_{2}$ is measured at stations in Germany. Figure 5d shows the plume reaching from Iceland into the North Sea, transported east and south compared to the situation from the day before. The two stations Kellerwald $\left(51.15^{\circ} \mathrm{N}\right.$ and $\left.9.03^{\circ} \mathrm{E}\right)$ and Bremerhaven $\left(53.56^{\circ} \mathrm{N}\right.$ and $8.57^{\circ} \mathrm{E}$ ) experience the plume differently. While for Bremerhaven the observed peak $\left(41.0 \mu \mathrm{gm}^{-3}\right)$ is short in duration, the peak lasts for 1 day at Kellerwald with an observed max-

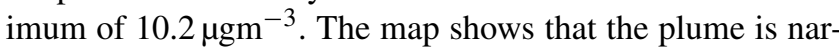
row for all three stations and the local spatial gradient is large.

A third plume is illustrated in Fig. 6 over northern Europe, occurring from the end of October to the beginning of November. Figure 6a shows the measured $\mathrm{SO}_{2}$ concentrations at a station in Oslo, Norway $\left(59.92^{\circ} \mathrm{N}\right.$ and $\left.10.76^{\circ} \mathrm{E}\right)$. There are four peaks measured from 29 to 31 October, with the highest one on 29 October $\left(50.4 \mu \mathrm{gm}^{-3}\right)$. The models runs show a contribution from Holuhraun $\mathrm{SO}_{2}$ over the same 3 days, but do not reach the high measured concentrations and the first plume is especially underestimated. On October 30, the plume is transported south-east to Poland. The Polish station in Sopot $\left(54.43^{\circ} \mathrm{N}\right.$ and $\left.18.58^{\circ} \mathrm{E}\right)$ experiences a short peak indicating that the model simulation happens a few hours earlier. The bas_hol simulation exhibits the most similar concentration evolution among the three model experiments.

Figure 7 shows wet deposition for the whole 3-month period at the Kårvatn station $\left(62.78^{\circ} \mathrm{N}\right.$ and $\left.8.88^{\circ} \mathrm{E}\right)$ in Norway. There are high levels, both observed and modelled during the last part of September. The model exhibits a clear peak value on 27 September, while the observations record deposition spread out over several days. Summed over the whole period, the observed deposition amounts to $15.9 \mathrm{gSm}^{-2} \mathrm{yr}^{-1}$ while the model simulated $20.0 \mathrm{gSm}^{-2} \mathrm{yr}^{-1}$. Comparisons at other stations in Norway show similar results (Supplement).

\subsection{Effects of the eruption on European pollution}

The above results show that, despite the Holuhraun eruption releasing large amounts of $\mathrm{SO}_{2}$, the stations in Europe often measured an increase in $\mathrm{SO}_{2}$ concentration only as 
(a)

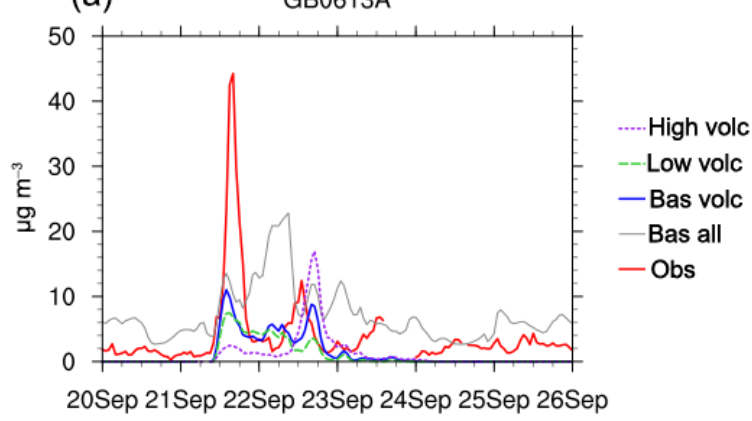

(c)

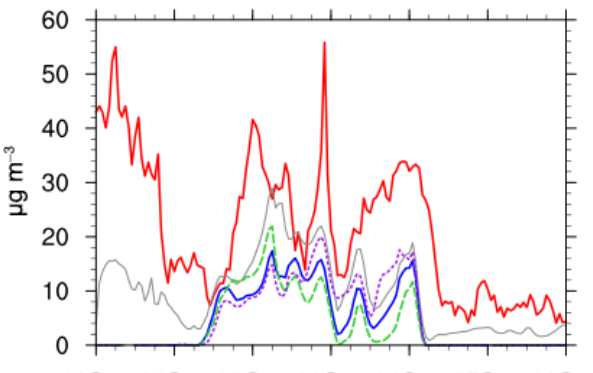

20Sep 21Sep 22Sep 23Sep 24Sep 25Sep 26Sep

(e)

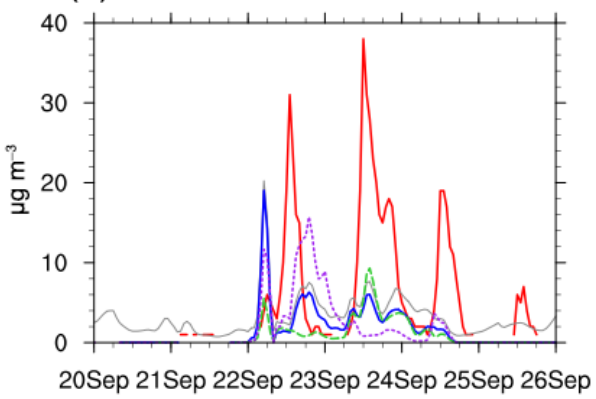

(b)

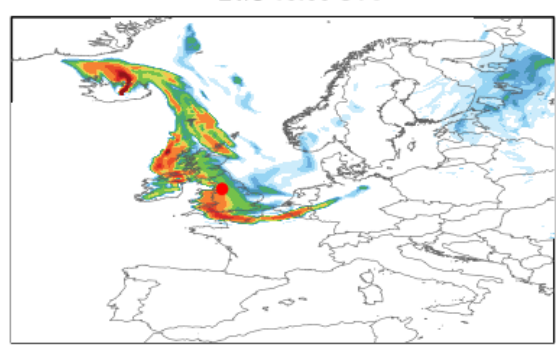

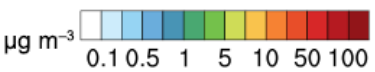

(d)

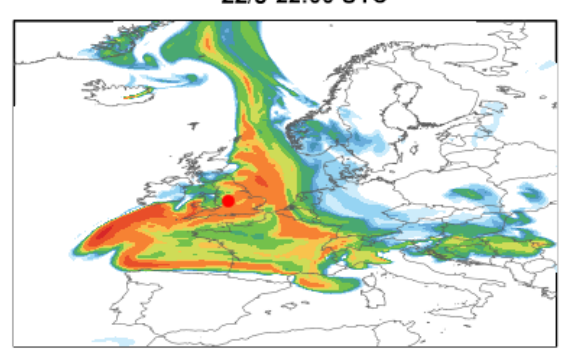

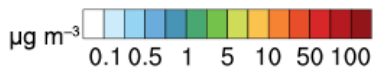

(f)

23/9 12:00 UTC

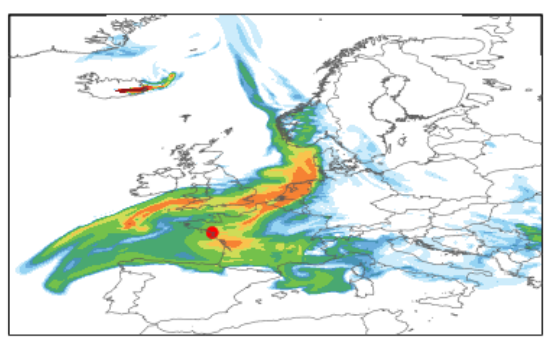

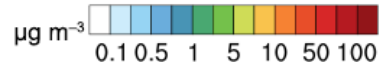

Figure 4. Left panels: time series of surface concentrations from 20 to 26 September 2014 for two stations, GB0613A, Manchester, $\mathrm{SO}_{2}$ (top), $\mathrm{PM}_{2.5}$ (middle) and FR23181, Saint-Nazaire, $\mathrm{SO}_{2}$ (bottom). The red line shows the measured surface concentrations, the grey line represents the modelled surface concentration in bas_hol ("bas all"). By subtracting from the modelled surface concentrations in the three model runs (bas_hol, low_hol and high_hol) the no_hol simulation values, the concentration due to volcanic eruption is calculated and shown in the blue, green and pink lines respectively. Right panels: corresponding map of simulated surface concentration due to the volcanic eruption from bas_hol, corresponding to the blue line in the left panels, for the time of the maximum observed concentration. The red dot on the map marks the position of the station.

short peaks (Gíslason et al., 2015; Schmidt et al., 2015). The model makes it possible to investigate the general impact on European air quality by Holuhraun volcanic emissions. Table 2 summarizes characteristic $\mathrm{SO}_{x}$ budget terms and surface concentrations for the European continental land area in the countries mentioned in Table 2. Concentration and deposition over the oceans are not included. To isolate the effect of the Holuhraun eruption on Iceland itself, the deposition and concentrations over Iceland are given in brackets.
The table shows that the Holuhraun emission flux in the study period corresponds to over 4.5 times the anthropogenic emission from the 31 European countries considered here (not including ship emissions). The anthropogenic emissions from Iceland are only $18 \mathrm{kt}$, while the $\mathrm{SO}_{2}$ emissions from Iceland increase by more than 300 times.

Over the 3 months, there is 1.32 times more $\mathrm{SO}_{x}$ wet deposition for the base run with Holuhraun emission than the reference simulation with no Holuhraun emission (no_hol). Table 2 shows that wet deposition over Europe is quite depen- 
(a)

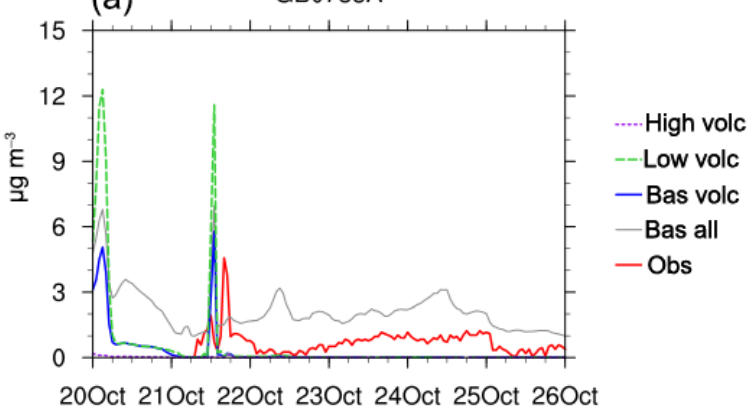

(c)

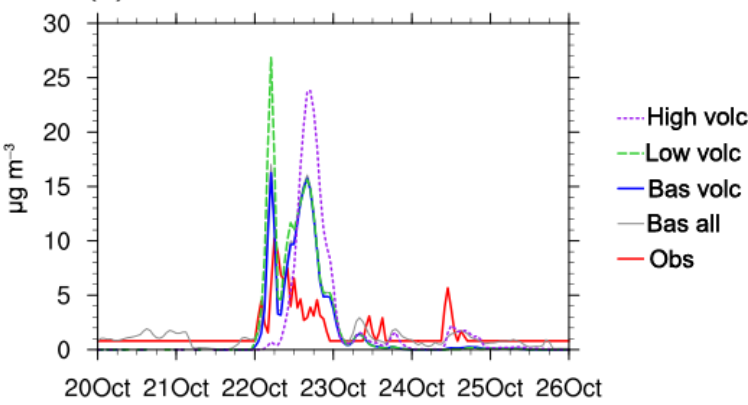

(e)

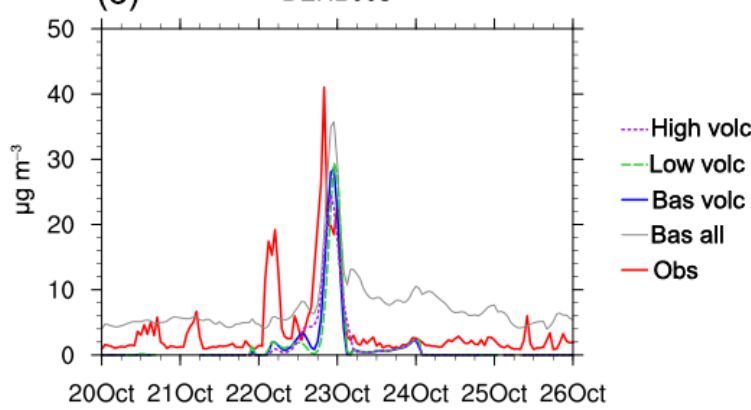

(b)

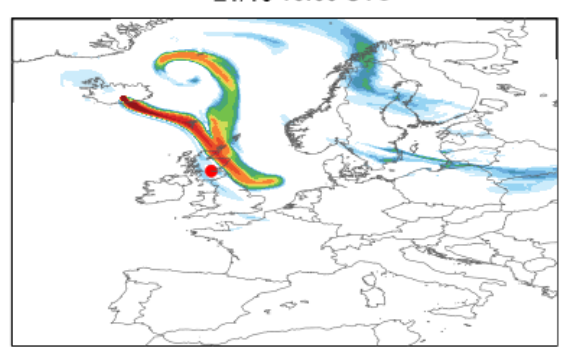

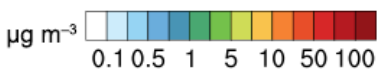

(d)

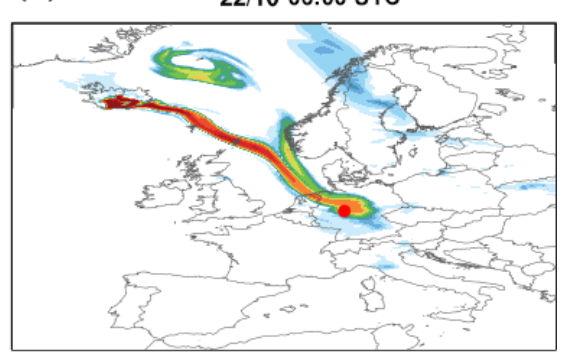

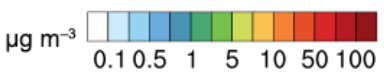

(f)

22/10 20:00 UTC

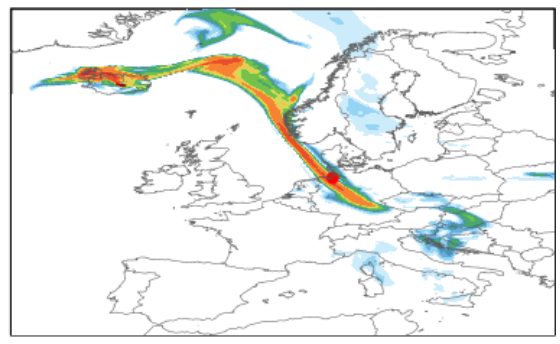

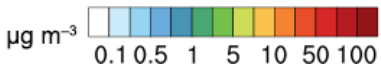

Figure 5. The same as Fig. 4, but from 20 to 26 October 2014 for three different stations GB0735A Grangemouth in Scotland, DEHE060 Kellerwald and DEHB005 Bremerhaven in Germany, all $\mathrm{SO}_{2}$.

dent on the emission height. The simulation with the emission highest in the atmosphere (high_hol) exhibits the highest wet deposition in Europe. For dry deposition, a $10 \%$ increase over Europe is found for all three model simulations with Holuhraun emissions. Close to the source, over Iceland, the deposition levels are very dependent on emission height, with dry deposition ranging from 8 to $409 \mathrm{kt}$.

Figure 8 shows the total deposition over Europe for the standard MACC model simulation with no Holuhraun emission (no_hol), the base model simulation (bas_hol) and the percent increase between these two model runs. Areas that experience the highest percent increase are also areas that have low levels in the model simulation with no emission at Holuhraun. Due to the Holuhraun emissions, Iceland has the highest $\mathrm{SO}_{x}$ deposition in Europe, and the coast of northern Norway shows depositions on the same level as the more polluted eastern Europe. Even though the previous section indicated that the model has higher wet deposition levels in northern Norway than observed, it also showed that it is very likely that the observed increases in $\mathrm{SO}_{x}$ deposition levels are due to the Holuhraun emissions.

The averaged $\mathrm{SO}_{2}$ surface concentration over Europe is higher than over Iceland under normal conditions. The volcanic emission caused the concentration level over Iceland to increase by a factor of 177 (for the low_hol simulation). Over the rest of Europe, the increase is about the same for all three Holuhraun simulations, even though the time series showed that the different simulations had peaks often arriv- 

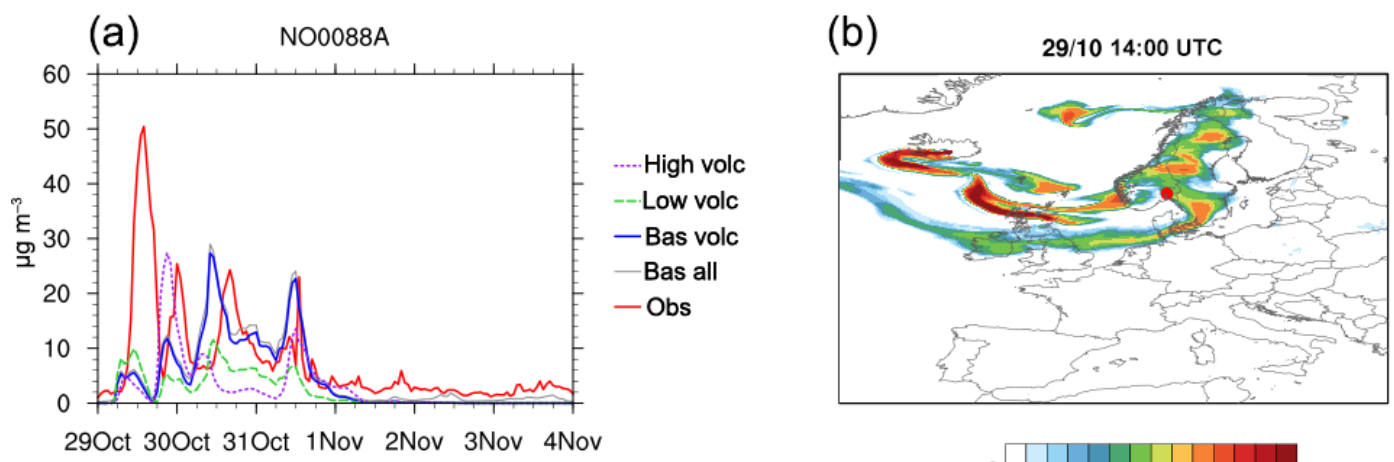

(c) PL0050A
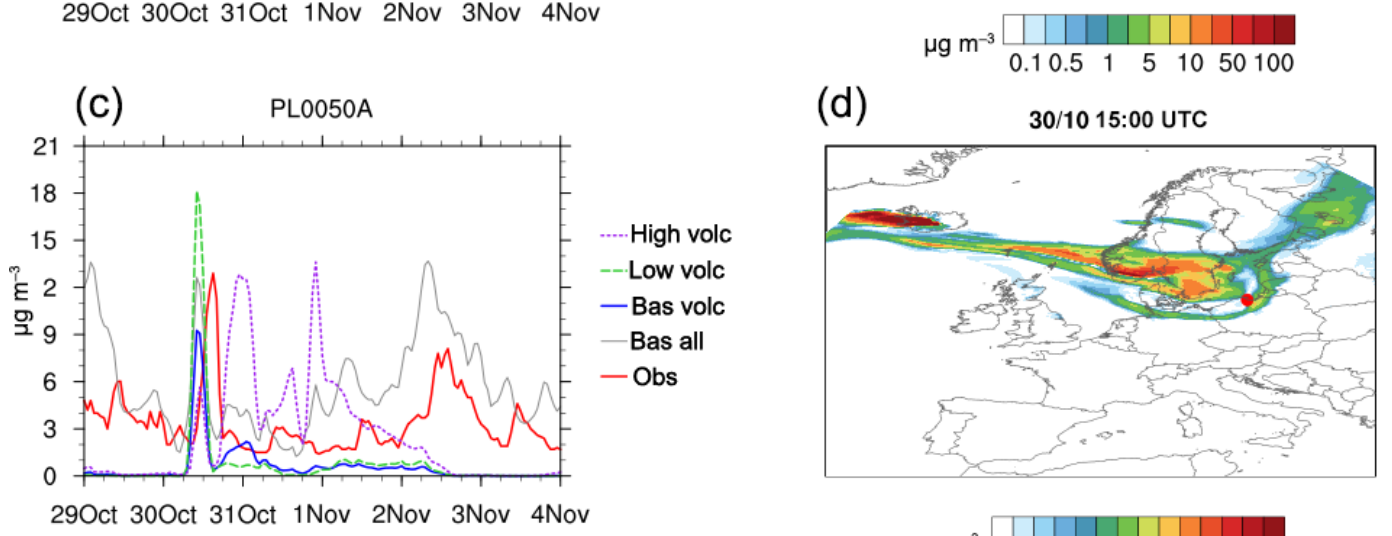

(d)

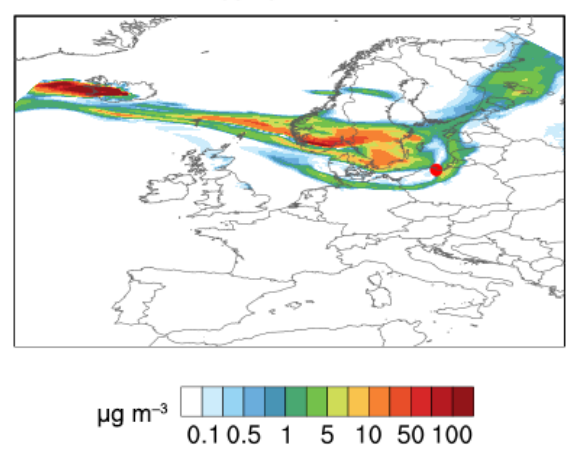

Figure 6. The same as Fig. 4 but from 29 October to 4 November 2014 for NO0088A Oslo, Norway and PL0050A in Sopot Poland, both $\mathrm{SO}_{2}$.

Table 2. Emissions, depositions and concentrations for the 28 European Union member states, Norway and Switzerland for the 3 months September, October, November 2014; emissions and depositions are totalled over the 3 month period, concentrations are the mean over the period for the 31 countries. Numbers in brackets are the contribution from Iceland, for emission and deposition. For concentrations, the number represents the average over Iceland. See simulation names and set-up in Table 1.

\begin{tabular}{llllll}
\hline Simulations: & no_hol & bas_hol & low_hol & high_hol & bas_hol/no_hol \\
\hline Emissions $\mathrm{SO}_{2}$ & 1257 & 1257 & 1257 & 1257 & 1 \\
$(\mathrm{kt})$ & $(18)$ & $(5980)$ & $(5980)$ & $(5980)$ & $(5.68)$ \\
$\mathrm{SO}_{x}$ Wet deposition & 1043 & 1382 & 1285 & 1465 & 1.32 \\
$(\mathrm{kt})$ & $(11)$ & $(1122)$ & $(1491)$ & $(472)$ & $(2.37)$ \\
$\mathrm{SO}_{x}$ Dry deposition & 481 & 529 & 524 & 526 & 1.10 \\
$(\text { kilotons })^{M e a n ~ S O}{ }_{2}$ surface conc. & $(4)$ & $(151)$ & $(409)$ & $(8)$ & $(1.40)$ \\
$\left(\mu \mathrm{g} \mathrm{m}^{-3}\right)$ & $(0.59)$ & 1.58 & 1.56 & 1.56 & 1.13 \\
$\mathrm{Mean} \mathrm{PM}_{2.5}$ surface conc. & 5.86 & 6.20 & 6.09 & 6.28 & 1.06 \\
$\left(\mu \mathrm{g} \mathrm{m}^{-3}\right)$ & $(0.82)$ & $(2.50)$ & $(3.13)$ & $(1.12)$ & $(3.06)$ \\
\hline
\end{tabular}

ing at different times. Vertical mixing, on average, levels off initial differences in emission height for volcanic plumes arriving in Europe.

The small increases in $\mathrm{PM}_{2.5}$ concentrations over Europe, as shown in Table 2, are due to increased sulfate production from volcanic $\mathrm{SO}_{2}$. However, $\mathrm{PM}_{2.5}$ is a collection of all aerosols under $2.5 \mu \mathrm{m}$, and the volcanic sulfate is changing total aerosol mass therefore relatively little. The table shows that Iceland has a lower average concentration than the rest of Europe for all four runs, even though Iceland is the source for the increase in aerosol pollution levels. The high_hol model simulation has a higher increase in $\mathrm{PM}_{2.5}$ concentration over Europe than the two other simulations. By contrast, the low_hol simulation finds the highest sulfate and $\mathrm{SO}_{x}$ deposition on Iceland itself, and possibly over the nearby ocean, which will lead to a smaller contribution to pollution levels over the rest of Europe. 


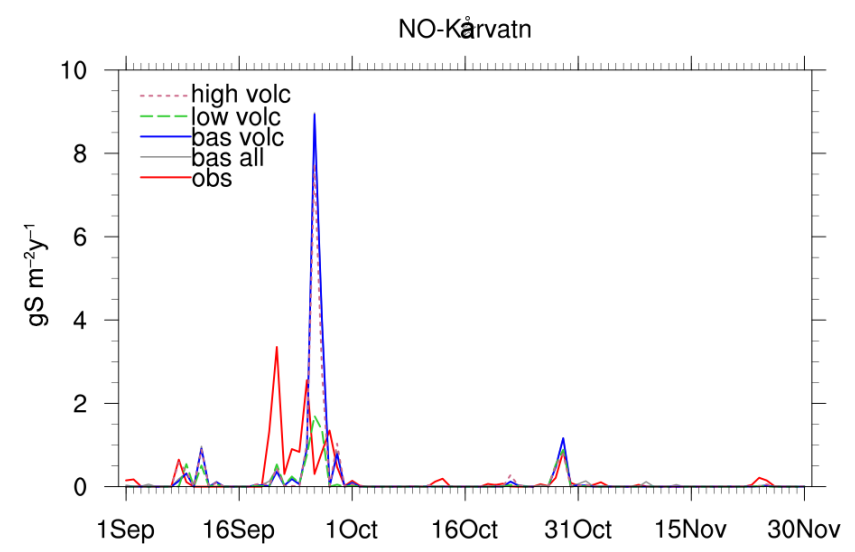

Figure 7. The same as Fig. 4, but September-November 2014 daily time series of $\mathrm{SO}_{x}$ total deposition at the Kårvatn station in Norway.

The distribution of $\mathrm{PM}_{2.5}$ from the no_hol and bas_hol simulation, plotted in Fig. 9, shows the same polluted and clean areas as in Fig. 8, although the increase is lower. Over north-western Norway and northern Norway, the increase is over $100 \%$. Figure $9 \mathrm{~b}$ shows that although the percentage increase is high, the $\mathrm{PM}_{2.5}$ concentrations in these areas are still among the least polluted in Europe. The high deposition levels in this region indicate that some of the $\mathrm{PM}_{2.5}$ is scavenged out.

WHO recommends a $24 \mathrm{~h}$ average mean concentration level of $25 \mu \mathrm{gm}^{-3}$ for $\mathrm{PM}_{2.5}$ not to be exceeded over 3 days in a year (WHO, 2005). Figure 10a shows that over the Benelux region, northern Germany and northern Italy this limit value is exceeded by up to 10 days during the 3 months studied. As the previous plot showed, these are regions with high average $\mathrm{PM}_{2.5}$ concentrations. Because the daily concentrations are already high, any increase in days in the model bas_hol simulation due to the Holuhraun emissions is also occurring in these regions, and the areas with the highest percent increase do not experience any days over the limit. The figure also shows that Northern Ireland experienced up to 2 exceedance days due to the volcanic eruption.

\section{Discussion}

The bias and variances between the model data and the satellite observations can be due to several factors. (a) The model emission flux may be under- or overestimated compared to the real emissions, model VCDs are therefore too low/too large compared to the observed ones. (b) The areas for which the column mass burdens have been computed depend on the VCD detection limit and the actual satellite data, so the retrieved model burdens depend on the position of the identified and observed $\mathrm{SO}_{2}$ cloud. If a simulated plume is displaced into an area where the satellite does not show any valid signal or no signal above detection limit, then this part of the model plume is ignored and may lead to underesti- mates by the model. (c) The presence of clouds can increase the uncertainty of the satellite retrieval. (d) The fluctuating real height of the $\mathrm{SO}_{2}$ plume may introduce additional bias between model and satellite VCDs. Schmidt et al. (2015) presented IASI (Infrared Atmospheric Sounding Interferometer) plume heights for the Bárðarbunga $\mathrm{SO}_{2}$ plume between 5.5 and $1.6 \mathrm{~km}$ derived from an area of $500 \mathrm{~km}$ around the volcanic location, and a mean IASI centre of mass height between 2.7 and $0.6 \mathrm{~km}$.

Schmidt et al. (2015) presented a comparison between model, satellite and ground observations for September. Mass burdens from OMI were derived using observed plume heights from the IASI instrument on the MetOp satellite. Both satellite data sets were compared with the model NAME (Numerical Atmospheric-dispersion Modelling Environment), a Lagrangian model, which was run for September, with sensitivity runs testing both emission height and emission flux. The model simulation with a plume height of $3 \mathrm{~km}$ and doubled emission flux $\left(\sim 1400 \mathrm{kgs}^{-1}\right)$ matched well with the OMI satellite data for the first days, while for the rest of September another simulation matched better, when emissions were similar to the constant emission term used in our study $\left(\sim 700 \mathrm{kgs}^{-1}\right)$. Their study and ours show that for the first days and at the end of September, the satellite data exhibit higher values than a model using an emission rate of $700-750 \mathrm{kgs}^{-1} \mathrm{SO}_{2}$. Our Holuhraun emission term in the three model simulations is constant throughout the simulations both with respect to the respective three emission heights and emission flux (see Table 1). Maximum fluxes of $1300 \mathrm{kgs}^{-1}$ were reported by Barsotti (2014). Gíslason et al. (2015) estimated a 2.5 times above-average emission term during the first 2.5 weeks of the eruption. Our assumption of a constant emission term is thus certainly a simplification.

However, here we suggest that overall understanding of the height of the plume is as important to achieve model agreement with the satellite data as emission intensity variations. The emission height is also variable, dependent on initial volcanic eruption characteristics and meteorological conditions like wind speed and stratification (Oberhuber et al., 1998). Table 1 contains the original mass burdens and the kernel-weighted mass burdens as described in Sect. 3.1. It also contains a scaled burden estimate, assuming that each of the three simulations should be corrected for bias against the satellite-derived burden. This scaling assumes that in each model simulation the height distribution may be correct. The resulting mass burdens from the three simulations differ by $60 \%$, computed as standard deviation. This may be seen as an uncertainty estimate associated with our limited knowledge of the real height of emission and dispersion of the $\mathrm{SO}_{2}$ plume from Bárðarbunga.

A better source estimate for the eruption is beyond the scope of this study, however, the fluctuations both in flux magnitude and emission height can explain some of the differences between satellite-observed and simulated concentrations, especially in the first days of September. 
(a)

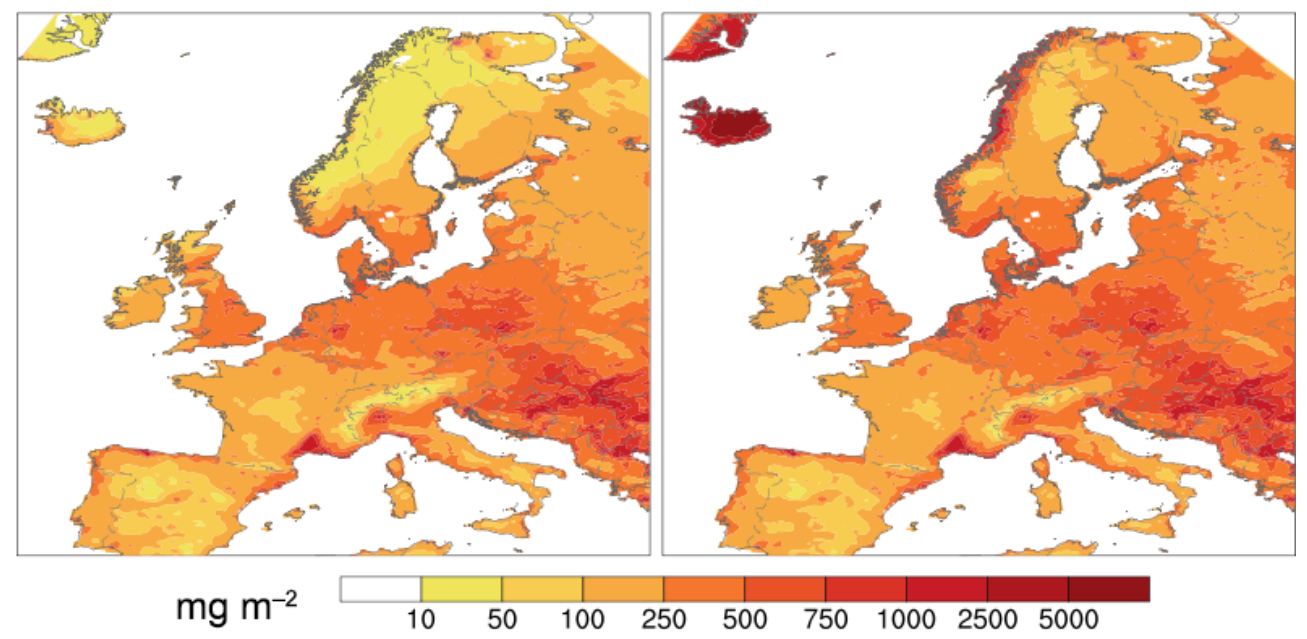

(c)

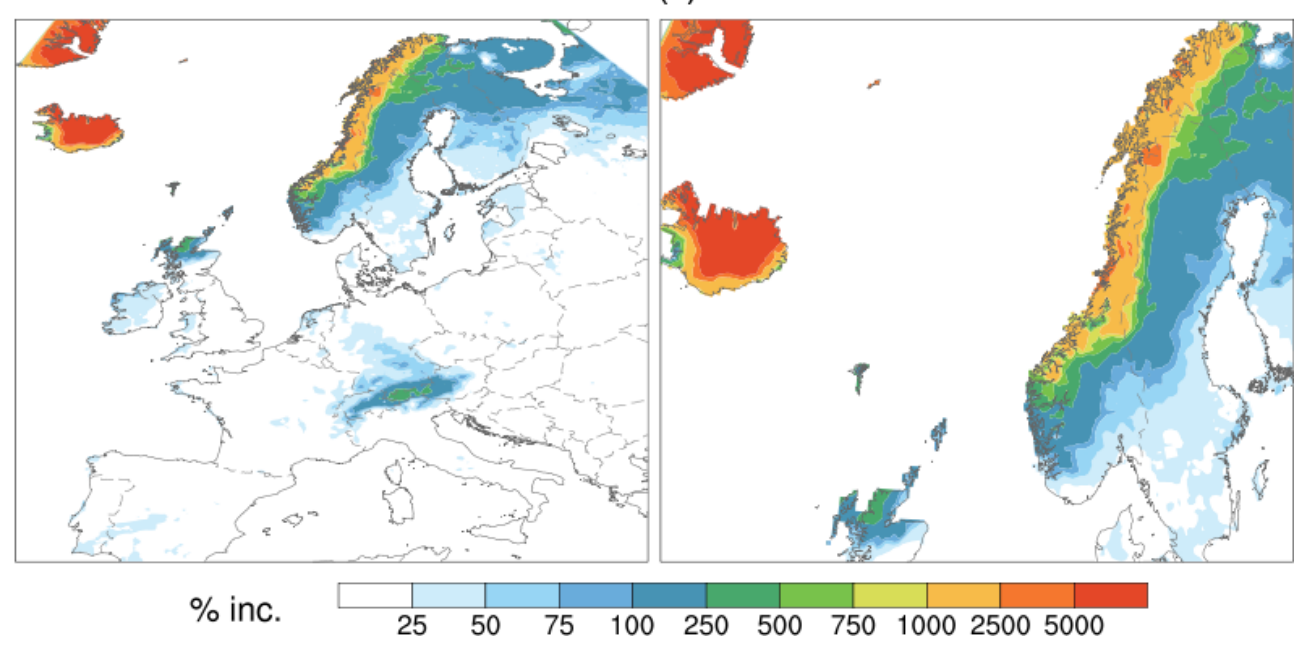

Figure 8. (a) Simulated total deposition of $\mathrm{SO}_{x}$ (wet and dry) over Europe from September to November 2014 for no_hol and (b) bas_hol simulations; (c) percent increase in $\mathrm{SO}_{x}$ deposition due to the Holuhraun emissions; (d) shows the same as (c) but zoomed into Norway and northern Europe.

Surface concentration comparisons presented in this study and in the Supplement show that the volcanic $\mathrm{SO}_{2}$ was observed as short singular peaks lasting a few hours or as a sequence of several peaks spread over a few days. Three episodes are picked where transnational transport is documented. The biggest difference between simulated and measured concentrations is found for the first of the three studied plumes during 20 to 26 September in Manchester (station GB0613A), Great Britain and Saint-Naizaire (station FR23181), France, with up to a factor of four differences. Both the measured and simulated concentrations during the September event were higher than the two later events, pointing to a more efficient transport of $\mathrm{SO}_{2}$ in this event. Higher emission fluxes up to a factor of 2 are supported by the satellite comparison on some of the days at the end of September. Changes in emission flux for the EMEP/MSC-W have been shown to have an almost linear change in concentrations (not shown here); even with doubled emissions during this event the model would still simulate surface concentrations well below those observed. Station data comparisons presented in Schmidt et al. (2015) for these days are similar, indicating that models have difficulties representing this period.

The discrepancies found between the model and observations suggest that the volcanic $\mathrm{SO}_{x}$ budget terms and average European surface concentrations presented in Table 2 contain errors. The model surface concentrations seem to be especially low compared to the observations; however the map plots in Figs. 4, 5, 6 show that sometimes modelled concentrations near the stations reached the observed levels. The area-averaged volcanic concentration contribution presented in Table 2 may therefore be close to reality. A more thorough study with a completed quality controlled data set is 
(a)

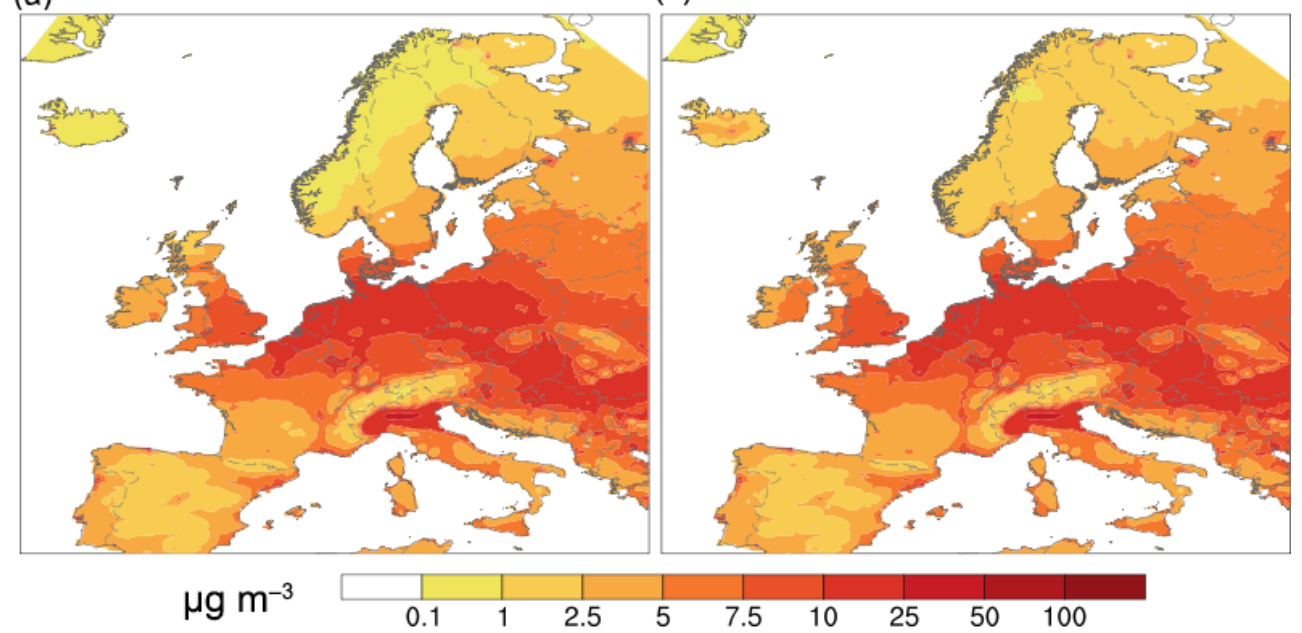

(c)

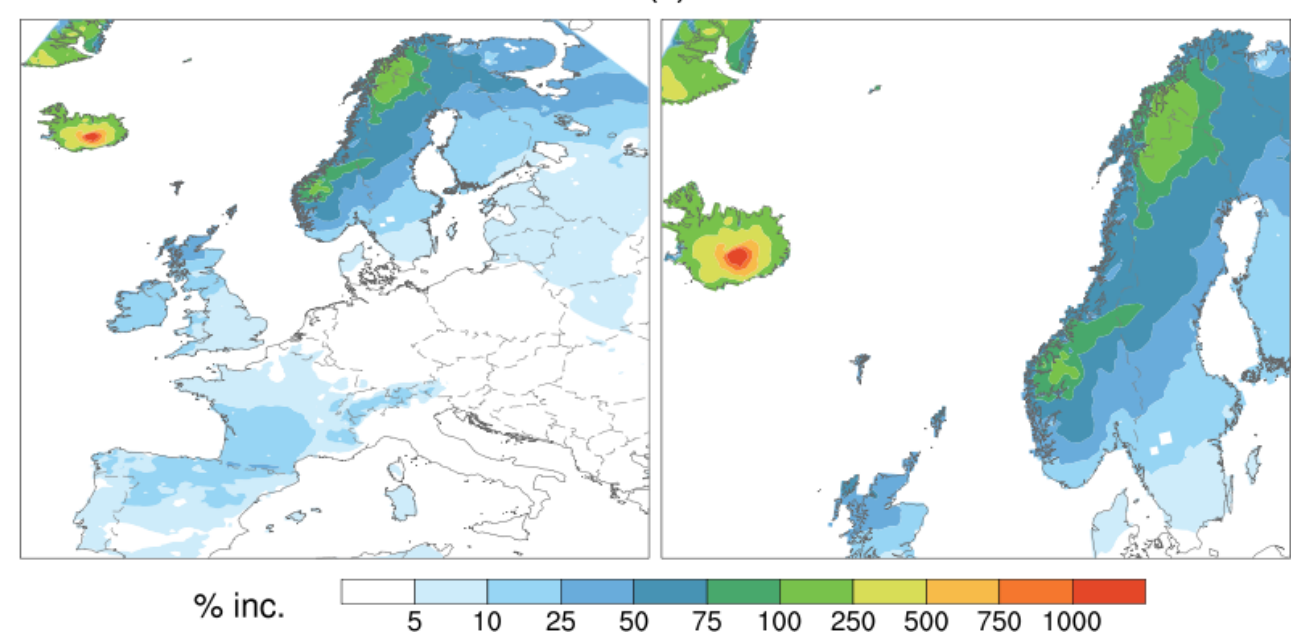

Figure 9. Shows the same as Fig. 8, but for average $\mathrm{PM}_{2.5}$ concentration over the 3 months.

needed to better estimate the increase in $\mathrm{SO}_{2}$ concentrations due to the eruption at the stations in the 2014 volcanic eruption episode.

Transport from an Icelandic volcano to Europe is caused by northerly and north-westerly winds. For the first plume, from 20 to 26 September, when the model shows low concentrations compared to the observations, there had been southerly winds for some time before strong northerly winds transported the $\mathrm{SO}_{2}$ cloud southward over Great Britain and France. Compared to the other two episodes, the $\mathrm{SO}_{2}$ surface concentration due to Holuhraun are higher over a larger area during this episode. The difficulty of the model in simulating the $\mathrm{SO}_{2}$ transport correctly is connected to the uncertainty in the emission term, the meteorology fields, the chemical reactions and deposition. Overall the comparison to observations shows, that our best-guess bas_hol model simulation matches best with the observed satellite column burdens, their time evolution and for some stations with the magnitude and timing of the observed surface concentration peaks.

The results in this study show that the sulfur deposition from September to November over northern Norway was at the same level as found in the most polluted regions in Europe. The emission ceiling's aim, set by the Gothenburg Protocol, was to reduce the $\mathrm{SO}_{x}$ emissions by $63 \%$ by 2010 from the 1990 levels in the European area of the convention of long-range transport of air pollutants (EMEP, 2015). Most countries have accomplished these reductions, and the sulfur deposition levels over Europe have decreased. The Holuhraun eruption changed the picture in some areas. Comparing observed deposition levels at Tustervatn station in central Norway, the simulated deposition is higher than the yearly observed averages since 1980 . Monthly observed values at this station during the 2011 Grimsvötn eruption show almost as high values as the bas_hol simulation. The time series from the Kårvatn station also shows that the in- 
(a)

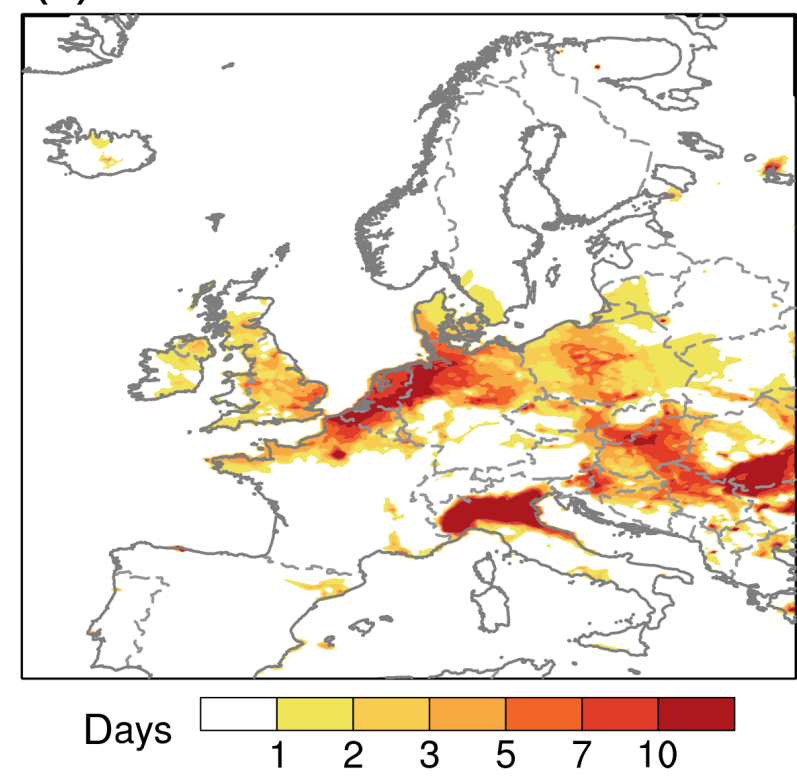

(b)

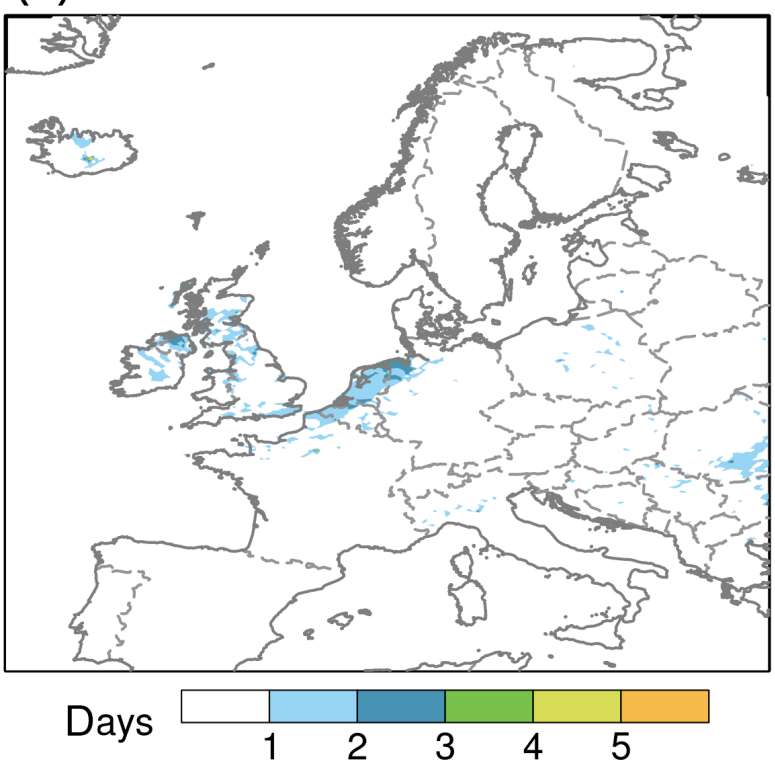

Figure 10. (a) Number of days with exceedances of $\mathrm{PM}_{2.5}$ in the period September through to November 2014, for the bas_hol model simulation. (b) The increase in days of $\mathrm{PM}_{2.5}$ exceedance from no_hol to bas_hol simulation, attributable to volcanic emissions.

creases are due to the Holuhraun volcanic eruption. Northern Norway is more susceptible for volcanic impact because of its geographical position, in addition to high frequency of precipitation on the western coast of Norway. Comparing the mean deposition levels over the 3 months in 2014 over Norway to model simulations with emissions from previous years, they are double those from the early 1990s (EMEP, 2015). Southern Norway experienced a sulfur deposition decrease of $40 \%$ from 1980 to 1995 due to emission abatement in Europe (Berge et al., 1999). The highest contributors to high deposition levels over southern Norway were the UK and Germany (18 and $15 \%$ respectively). Norway also experienced a high percent increase in $\mathrm{PM}_{2.5}$ concentrations in 2014. The $\mathrm{PM}_{2.5}$ levels over Scandinavia are low, and a small increase in the concentrations leads to high percent increases. The increase over land shows a similar pattern as the results found in Schmidt et al. (2011) for a hypothetical Laki eruption. Even though the highest increase is over Scandinavia and Scotland, the concentrations are too low to exceed the $25 \mu \mathrm{g} \mathrm{m}^{-2}$ limit. Already polluted regions like the Benelux region experience more days with exceedances as well as Northern Ireland.

\section{Conclusions}

The increase in emitted $\mathrm{SO}_{2}$ to the atmosphere caused by the volcanic eruption at Holuhraun was observed by satellite and detected at several stations over Europe (Schmidt et al., 2015; Gíslason et al., 2015). Model simulations with the
EMEP MSC-W model with emissions from Holuhraun over the period from September to November 2014 have been carried out to investigate the model capability to simulate such events, and also to study the impact of the increased emissions on concentrations and depositions over Europe.

The first 2 months of the model simulations are compared to satellite retrievals from OMI. The retrievals use an assumed plume height of $7 \mathrm{~km}$. Averaging kernels from the satellite data are applied on the model data to compare the model data to the satellite. Because of the weighting, the satellite retrieved mass burden values are dependent on both vertical placement and amount of $\mathrm{SO}_{2}$. Two sensitivity model simulations with different Holuhraun emission heights are compared to the satellite data together with the best-guess base simulation. After the kernel is applied, the results are more comparable to the satellite data. Constraining the $\mathrm{SO}_{2}$ column burden with the satellite data while using the kernel along with the three simulated height distributions of $\mathrm{SO}_{2}$, we estimate that the median of the daily burdens may have been between 13 and $40 \mathrm{kt}$ in the North Atlantic area under investigation.

The model simulations are also compared to observed concentrations at stations over Europe for three different events with high concentrations measured due to the Holuhraun emissions. For all the events, the timing of the model peaks is compared to the observed peaks in concentration. There is a better timing in the two model simulations in which the emissions are injected lowest into the atmosphere than for the sensitivity run with the highest emission height. Due to 
a special transport pattern of $\mathrm{SO}_{2}$ during the first event, observed concentrations are higher here than during the later events, and the difference between models and observations is largest. $\mathrm{PM}_{2.5}$ concentration during this first event is comparable to observations. Uncertainties in the model simulations increase by the length of transport, and some near misses of the narrow plumes can clearly explain differences between models and observation. To make a better assessment of model performance during the whole volcanic eruption, better quality checked station data are needed. Comparison between the model and wet deposition observations over Norway show significant and high contributions from the eruption, although the model overpredicts values at the stations studied and other stations to be found in the Supplement.

Studying the changes in pollution levels over Europe, increased $\mathrm{SO}_{x}$ wet deposition is most noticeable. In the 3month base simulation there is $32 \%$ more sulfate wet deposition found than in the model simulation with no Holuhraun emission, accounted for over the 28 European Union countries, Norway and Switzerland. The regions that have the highest increase, apart from Iceland, are northern Scandinavia and Scotland, regions that are among the least polluted in Europe. In particular, the coast of northern Norway, with a percent increase in total deposition of over $1000 \%$, shows levels equal to the most polluted regions in Europe Seen against the long-term record of observed levels of deposition since 1980 at the Tustervatn station in central Norway, the 2014 deposition values stand out and are only exceeded during the Grimsvötn eruption in 2011. We also find that high $\mathrm{SO}_{x}$ wet deposition values measured at the Kårvatn station in 2014 on the coast of western Norway are very likely due to the Holuhraun emissions.

The difference in $\mathrm{SO}_{2}$ concentrations over Europe between the no_hol and model simulations with Holuhraun emission is around $13 \%$ and increases occur as short peaks in concentration levels from a few hours to some days. Due to the underestimation seen at stations during September, the uncertainty of this number is large and the simulated volcanic contribution is possibly too small. For $\mathrm{PM}_{2.5}$ concentration, the volcanic increase is $6 \%$, and the model shows better agreement with station observations. The biggest difference in percent increase is seen over Scandinavia and Scotland, however these regions are among the cleanest in Europe, also with the added sulfur caused by the Holuhraun emissions. The areas that show an increase in number of days with over $25 \mu \mathrm{gm}^{-2} \mathrm{PM}_{2.5}$ concentrations are those that are already polluted. Even with high emissions from the volcanic fissure at Holuhraun, the increase in pollution levels over Europe was relatively small, with only transient episodes associated with high increases in $\mathrm{SO}_{2}$ concentration.

\section{The Supplement related to this article is available online} at doi:10.5194/acp-16-9745-2016-supplement.
Acknowledgements. Most of the work done for this paper is funded by the Norwegian ash project financed by the Norwegian Ministry of Transport and Communications and AVINOR. Model and support is also appreciated through the Cooperative Programme for Monitoring and Evaluation of the Long-range Transmission of Air Pollutants in Europe (No: ECE/ENV/2001/003). The observations are made available through the EEA UTD database (http://www.eionet.europa.eu/aqportal) and the MACC project (MACC III project number 633080) obtained with the much appreciated help of Álvaro Valdebenito. Wenche Aas and Paul Eckhardt are thanked for provision of recent measurements of wet deposition measurements in northern Norway, included in the EBAS database. This work has also received support from the Research Council of Norway (Programme for Supercomputing) through CPU time granted at the super computers at NTNU in Trondheim.

Edited by: Y. Balkanski

Reviewed by: two anonymous referees

\section{References}

Barsotti, S.: 100 Days of Gas Release at Holuhraun, Vedur.is, http:// en.vedur.is/pollution-and-radiation/volcanic-gas/measurements/ (last access: 26 March 2015), 2014.

Berge, E., Bartnicki, J., Olendrzynski, K., and Tsyro, S.: Long-term trends in emissions and transboundary transport of acidifying air pollution in Europe, J. Environ. Manage., 57, 31-50, 1999.

Brenot, H., Theys, N., Clarisse, L., van Geffen, J., van Gent, J., Van Roozendael, M., van der A, R., Hurtmans, D., Coheur, P.-F., Clerbaux, C., Valks, P., Hedelt, P., Prata, F., Rasson, O., Sievers, K., and Zehner, C.: Support to Aviation Control Service (SACS): an online service for near-real-time satellite monitoring of volcanic plumes, Nat. Hazards Earth Syst. Sci., 14, 1099-1123, doi:10.5194/nhess-14-1099-2014, 2014.

EMEP MSC-W: Transboundary acidification, eutrophication and ground level ozone in Europe 2013, EMEP Status Report 1/2015, 2015.

Gettelman, A., Schmidt, A., and Kristjansson, J. E.: Icelandic volcanic emissions and climate, Nat. Geosci, 8, 243-243, 2015.

Gíslason, S. R., Stefánsdóttir, G., Pfeffer, M. A., Barsotti, S., Jóhannsson, T., Galeczka, I., Bali, E., Sigmarsson, O., Stefánsson, A., Keller, N. S., Sigurdsson, Á., Bergsson, B., Galle, B., Jacobo, V. C., Arellano, S., Aiuppa, A., Jónasdóttir, E. B., Eiríksdóttir, E. S., Jakobsson, S., Guðfinnsson, G. H., Halldórsson, S. A., Gunnarsson, H., Haddadi, B., Jónsdóttir, I., Thordarson, T., Riishuus, M., Högnadóttir, T., Dürig, T., Pedersen, G. B. M., Höskuldsson, Á., and Gudmundsson, M. T.: Environmental pressure from the 2014-15 eruption of Bárðarbunga volcano, Iceland, Geochem. Persp. Lett., 1, 84-93, 2015.

Grattan, J., Durand, M., and Taylor, S.: Illness and elevated Human Mortality in Europe Coincident with the Laki Fissure eruption. Vocanic Degassing: Geol. Soc, SP 213, The Geological Society of London, 410-414, 2003.

Ialongo, I., Hakkarainen, J., Kivi, R., Anttila, P., Krotkov, N. A., Yang, K., Li, C., Tukiainen, S., Hassinen, S., and Tamminen, J.: Comparison of operational satellite $\mathrm{SO}_{2}$ products with groundbased observations in northern Finland during the Icelandic 
Holuhraun fissure eruption, Atmos. Meas. Tech., 8, 2279-2289, doi:10.5194/amt-8-2279-2015, 2015.

Levelt, P. F., van den Oord, G. H. J., Dobber, M. R., Mälkki, A., Visser, H., de Vries, J., Stammes, P., Lundell, J., and Saari H.: The Ozone Monitoring Instrument, IEEE T. Geosci. Remote, 44, 1093-1101, doi:10.1109/TGRS.2006.872333, 2006.

Kuenen, J. J. P., Visschedijk, A. J. H., Jozwicka, M., and Denier van der Gon, H. A. C.: TNO-MACC_II emission inventory; a multiyear (2003-2009) consistent high-resolution European emission inventory for air quality modelling, Atmos. Chem. Phys., 14, 10963-10976, doi:10.5194/acp-14-10963-2014, 2014.

Moxnes, E. D., Kristiansen, N. I., Stohl, A., Clarisse, L., Durant, A., Weber, K., and Vogel, A.: Separation of ash and sulphur dioxide during the 2011 Grimsvötn eruption, J. Geophy. Res.-Atmos., 119, 7477-7501, 2014.

Oberhuber, J. M., Herzog, M., Graf, H., and Schwanke, K.: Volcanic plume simulation on large scales, J. Volcanol. Geoth. Res., 87, 29-53, 1998.

Rodgers, C. D.: Inverse Methods for Atmospheric Sounding: Theory and Practice, World Sci., Singapore, 2000.

Schmidt, A., Ostro, B., Carslaw, K. S., Wilson, M., Thordarson, T., Mann, G. W., and Simmons, A. J.: Excess mortality in Europe following a future Laki-style Icelandic eruption, P. Natl. Acad. Sci. USA, 108, 15710-15715, 2011.

Schmidt, A., Leadbetter, S., Theys, N., Carboni, E., Witham, C. S., Stevenson, J. A., Birch, C. E, Thordarson, T., Turnock, S., Barsotti, S., Delaney, L., Feng, W., Grainger, R. G., Hort, M. C., Höskuldsson, Á., Ialongo, I., Ilyinskaya, E., Jóhannsson, T., Kenny, P., Mather, T. A., Richards, N. A. D., and Shepherd, J.: Satellite detection, long-range transport, and air quality impacts of volcanic sulphur dioxide from the 2014-2015 flood lava eruption at Bárðarbunga (Iceland), J. Geophys. Res.-Atmos., 120, 9739-9757, doi:10.1002/2015JD023638, 2015.

Sears, T. M., Thomas, G. E., Carboni, E., A Smith, A. J., and Grainger, R. G.: $\mathrm{SO}_{2}$ as a possible proxy for volcanic ash in aviation hazard avoidance, J. Geophys. Res.-Atmos., 118, 56985709, 2013

Sigmundsson, F., Hooper, A., Hreinsdottir, S., Vogfjord, K. S., Ofeigsson, B. G., Heimsson, E. R., Dumont, S., Parks, M., Spaans, K., Gudmindsson, G. B., Drouin, V., Arnadottir, T., Jonsdottir, K., Gudmundsson, M. T., Hognadottir, T., Fridriksdottir, H. M., Hensch, M., Einarsson, P., Magnusson, E., Samsonov, S., Brandsdottir, B., White, R. S., Agustdottir, T., Greenfield, T., Green, R. G., Hjartardottir, A. R., Pedersen, R., Bennet, R. A., Geirsson, H., La Femina, P. C., Bjornsson, H., Palsson, F., Sturkell, E., Bean, C. J., Mollhoff, M., Braiden, A. K., and Eibl, E. P. S.: Segmented lateral dyke growth in a rifting event at Barðarbunga volcanic system, Iceland, Nature, 517, 191-195, 2015.
Simpson, D., Benedictow, A., Berge, H., Bergström, R., Emberson, L. D., Fagerli, H., Flechard, C. R., Hayman, G. D., Gauss, M., Jonson, J. E., Jenkin, M. E., Nyíri, A., Richter, C., Semeena, V. S., Tsyro, S., Tuovinen, J.-P., Valdebenito, Á., and Wind, P.: The EMEP MSC-W chemical transport model - technical description, Atmos. Chem. Phys., 12, 7825-7865, doi:10.5194/acp-127825-2012, 2012.

Theys, N., De Smedt, I., van Gent, J., Danckaert, T., Wang, T., Hendrick, F., Stavrakou, T., Bauduin, S., Clarisse, L., Li, C., Krotkov, N., Yu, H., Brenot, H., and Van Roozendael, M.: Sulphur dioxide vertical column DOAS retrievals from the Ozone Monitoring Instrument: Global observations and comparison to groundbased and satellite data, J. Geophys. Res.-Atmos., 120, 2470 2491, doi:10.1002/2014JD022657, 2015.

Thomas, H. E. and Prata, A. J.: Sulphur dioxide as a volcanic ash proxy during the April-May 2010 eruption of Eyjafjallajökull Volcano, Iceland, Atmos. Chem. Phys., 11, 6871-6880, doi:10.5194/acp-11-6871-2011, 2011.

Thordarson, T. and Self, S.: The Laki (Skaftár Fires) and Grimsvötn eruptions in 1783-1785, B. Volcanol., 55, 233-263, 1993.

Thordarson, T. and Self, S.: Atmospheric and environmental effects of the 1783-1784 Laki eruption: A review and reassessment, J. Geophys. Res.-Atmos., 108, AAC 7-1-AAC 7-29, 2003.

Thordarson, T. and Hartley, M.: Atmospheric sulphur loading by the ongoing Nornahraun eruption, North Iceland, EGU General Assembly Conference Abstracts, 17, 2015EGUGA, 1710708T, 2015.

Tørseth, K., Aas, W., Breivik, K., Fjæraa, A. M., Fiebig, M., Hjellbrekke, A. G., Lund Myhre, C., Solberg, S., and Yttri, K. E.: Introduction to the European Monitoring and Evaluation Programme (EMEP) and observed atmospheric composition change during 1972-2009, Atmos. Chem. Phys., 12, 5447-5481, doi:10.5194/acp-12-5447-2012, 2012.

World Health Organisation (WHO): Air quality guidelines, Global update 2005, Particulate matter, ozone, nitrogen dioxide and sulphur dioxide, http://www.who.int/phe/health_topics/outdoorair/ outdoorair_aqg/en/ (last access: 9 October 2015), World Health Organisation, European Centre for Environment and Health Bonn Office, ISBN 9289021922005.

Yang, K., Krotkov, N. A., Krueger, A. J., Carn, S. A., Bhartia, P. K., and Levelt, P. F.: Retrieval of large volcanic $\mathrm{SO}_{2}$ columns from the Aura Ozone Monitoring Instrument: Comparison and limitations, J. Geophys. Res.-Atmos., 112, D24S43, doi:10.1029/2007JD008825, 2007. 